\title{
STRATEGI PENGEMBANGAN WISATA BAHARI PANTAI MALALAYANG, KOTA MANADO, SULAWESI UTARA
}

\author{
Fitridamayanti Razak \\ Benu Olfie L. Suzana \\ Gene H. M. Kapantow
}

\begin{abstract}
Tourism is one of the largest industries ever in the world, so complex with the involvement of many parties and aspects and has a tremendous turnover. Tourism development is generally directed as a key sector for promoting economic growth, increasing local revenues, empowering the people's economy, expanding employment and business opportunities, and improving the introduction and marketing of products in order to improve the welfare of the people. This study aims to formulate the development strategy of Malalayang Coastal Tourism of Manado City. This research uses descriptive method where data are collected, analyzed and descripted by using qualitative approach. Qualitative approach describes the responses of respondents to marine tourism based on the given questionnaire. Data collection conducted through field observation, interview and literature study. The results of this study indicate that the strategy of marine tourism development Malalayang Beach lies in the position of quadrant I or lies between external opportunities and internal strength. Strategy of maritime tourism development Malalayang Beach Manado City is to maintain and preserve the surrounding environment, the need for the development of facilities and facilities of tourism objects, the rearrangement of "sabua bulu" as a culinary place and the need for management of the government and private sector to be more focused and run well and both The parties agreed to cooperate to develop sustainable tourism Malalayang Coastal..
\end{abstract}

Keyword : strategy, devolepment,marine tourism, Malalayang Coastal

\begin{abstract}
ABSTRAK
Pariwisata merupakan salah satu industri terbesar yang pernah ada di dunia ini, begitu kompleks dengan melibatkan banyak pihak dan aspek serta memiliki omset yang luar biasa. Pengembangan kepariwisataan pada umumnya diarahkan sebagai sektor andalan untuk mendorong pertumbuhan ekonomi, peningkatan pendapatan daerah, memberdayakan perekonomian masyarakat, memperluas lapangan kerja dan kesempatan berusaha, serta meningkatkan pengenalan dan pemasaran produk dalam rangka meningkatkan kesejahteraan masyarakat. Penelitian ini bertujuan untuk merumuskan strategi pengembangan Wisata Bahari Pantai Malalayang Kota Manado. Penelitian ini menggunakan metode deskriptif dimana data dikumpulkan, dianalisis dan deskripsikan dengan menggunakan pendekatan kualitatif. Pendekatan kualitatif menggambarkan tanggapan responden terhadap wisata bahari berdasarkan kuisioner yang diberikan. Pengumpulan data melalui observasi lapangan, wawancara dan studi literatur. Hasil Penelitian ini menunjukkan bahwa strategi pengembangan wisata bahari Pantai Malalayang terletak pada posisi kuadran I atau terletak antara peluang eksternal dan kekuatan internal. Strategi pengembangan wisata bahari Pantai Malalayang Kota Manado adalah menjaga dan melestarikan lingkungan sekitar, perlu adanya pengembangan fasilitas sarana dan prasarana obyek wisata, penataan kembali "sabua bulu" sebagai tempat kuliner dan perlu adanya pengelolaan dari pihak pemerintah dan swasta agar lebih terarah dan berjalan dengan baik serta kedua belah pihak sepakat bekerjasama untuk mengembangkan obyek wisata Pantai Malalayang secara berkelanjutan.
\end{abstract}

Kata kunci : Strategi, pengembangan, wisata bahari Pantai Malalayang. 


\section{PENDAHULUAN}

\section{Latar Belakang}

Pengembangan kepariwisataan pada umumnya diarahkan sebagai sektor andalan untuk mendorong pertumbuhan ekonomi, peningkatan pendapatan daerah, memberdayakan perekonomian masyarakat, memperluas lapangan kerja dan kesempatan berusaha, serta meningkatkan pengenalan dan pemasaran produk dalam rangka meningkatkan kesejahteraan masyarakat. Pengembangan wisata harus merupakan pengembangan yang terencana secara menyeluruh sehingga dapat diperoleh manfaat yang optimal bagi masyarakat.

Sektor pariwisata sebagai suatu kegiatan ekonomi memiliki mata rantai yang sangat panjang sehingga banyak menampung kesempatan kerja bagi masyarakat sekitarnya yang selanjutnya akan menyebabkan pendapatan masyarakat meningkat dari hasil penjualan barang dan jasa melalui usaha restoran, hotel, biro perjalanan, penjualan barang cinderamata dan sebagainya. Semakin banyak wisatawan yang datang maka akan semakin banyak devisa yang diterima dan pada akhirnya akan mendorong pembangunan sarana dan prasarana wisata lainnya (Spillane, 1994).

Kota Manado merupakan destinasi yang unik dan berbeda dengan destinasi lain di Indonesia. Kekhasan Kota Manado antara lain adalah sebagai wilayah yang memiliki potensi wisata bahari yang luas dan banyak. Luas Kota Manado adalah $157.26 \mathrm{Km}^{2}$ setelah proses reklamasi di Kawasan Pantai Manado yang saat ini dikenal dengan nama kawasan Boulevard, luas ini bertambah sebesar 67 ha dan secara administrative Kota Manado terbagi atas 9 (Sembilan) kecamatan dan 80 (delapan puluh) kelurahan/desa dan termasuk di dalamnya 3 (tiga) wilayah pulau yang menjadi bagian dari wilayah administrasi pemerintah Kota Manado yaitu: Pulau Bunaken, Pulau Siladen dan Pulau Manado Tua yang semuanya terletak di Kecamatan Bunaken. Sulawesi Utara memiliki banyak obyek wisata unggulan diantaranya yaitu Taman Laut Bunaken yang dikenal sejak lama oleh wisatawan lokal, domestik maupun mancanegara.

Pantai Malalayang adalah salah satu obyek wisata yang paling menarik dan banyak di kunjungi wisatawan lokal di Kota Manado, ini di karenakan tempat wisata Pantai Malalayang sangat dekat dengan pusat Kota Manado yakni berjarak kurang lebih 4 kilometer dan untuk sampai ke Pantai Malalayang hanya membutuhkan waktu sekitar 10 menit serta memiliki potensi wisata berupa biota laut dan keanekaragman hayati dan lautnya yang sangat menyenangkan untuk kegiatan air seperti berenang, snorkeling, diving dan sebagainya serta lokasinya sangat strategis untuk dikembangkan. Penelitian ini bertujuan untuk merumuskan strategi pengembangan Wisata Bahari Pantai Malalayang Kota Manado.

\section{METODE PENELITIAN}

\section{Waktu Dan Tempat Penelitian}

Penelitian ini dilaksanakan di wisata bahari Pantai Malalayang yang berada dalam wilayah administrasi Kota Manado, tepatnya di Kecamatan Malalayang Provinsi Sulawesi Utara dimana penelitian ini dilaksanakan pada bulan Januari sampai bulan Mei 2017. Jenis penelitian yang dilakukan yaitu observasi lapangan, wawancara/Interview dan studi literatur.

\section{Metode dan Pengumpulan Data}

Penelitian ini menggunakan metode deskriptif dimana data dikumpulkan, dianalisis dan deskripsikan dengan menggunakan pendekatan kualitatif. pendekatan kualitatif menggambarkan tanggapan responden terhadap wisata bahari berdasarkan kuisioner yang diberikan. Metode pengumpulan data meliputi data primer dan sekunder. Data primer diperoleh dengan melakukan observasi lapangan baik dari pengamatan secara fisik ataupun wawancara terhadap beberapa narasumber terkait mengenai lokasi penelitian.

Data sekunder diperoleh dari studi literatur mengenai kondisi fisik dasar, profil wisata bahari Pantai Malalayang dan data-data penelitian terlebih dahulu yang terkait dengan penelitian ini, serta dengan melakukan survei institusional. Institusi yang dituju untuk mendukung penelitian ini adalah institusi yang membawahi beberapa bidang yang terkait dengan pengelolaan wisata bahari, seperti : Kantor BPS, Kantor Bappeda serta Dinas 
Pariwisata dan lain-lain. Adapun jumlah responden dalam penelitian ini sebanyak 20 orang. Ditentukan secara accidental dan purposive sampling. Teknik accidental yang dimaksud menyangkut teknik penentuan sampel secara kebetulan, sedangkan purposive sampling meliputi teknik penentuan sampel dengan pertimbangan tertentu.

\section{Analisis Data}

Pengelolaan data digunakan dengan analisis SWOT dan diproses melalui faktorfaktor internal dan eksternal. Kemudian melakukan penyusunan strategi dengan menggunakan analisis SWOT. Semua elemen dalam SWOT akan dijaring melalui jawaban responden terhadap pertanyaan yang diajukan. Berikut adalah tahap-tahap dalam penyususnan analisis SWOT : Pembuatan Matrik Faktor Strategi Internal, Pembuatan Matrik Faktor Strategi Eksternal, Analisis Internal Eksternal, Analisi SWOT.

\section{HASIL PENELITIAN}

\section{Analisis Faktor IFAS (Internal Strategic Analysis Summary).}

Setelah melakukan identifikasi faktorfaktor kunci internal, maka dilanjutkan denganmemberikan bobot dan rating pada faktor kunci internal bertujuan untuk mengklasifikasi faktor-faktor yang menjadi kekuatan atau kelemahan pengembangan Wisata Bahari Pantai Malalayang, hasil dari pemberian rating dan bobot tersebut akan menunjukkan apakah faktor tersebut merupakan kekuatan yang besar atau kecil serta kelemahan besar atau kecil. Bobot menunjukan prioritas kepentingan faktorfaktor tersebut bagi pengembangan wisata bahari pantai malalayang. Perhitungan bobot faktor tersebut dilakukan dengan membuat tabulasi data skor IFAS. Untuk lebih jelasnya dapat diuraikan pada Tabel 1.

Berdasarkan hasil data perhitungan pada tabel IFAS diperoleh total skor bobot untuk kekuatan dan kelemahan adalah 3,817 yang menandakan Kawasan Wisata Bahari Pantai Malalayang berada pada posisi kuat dalam memanfaatkan kekuatan untuk menghadapi kelemahan yang dihadapi dalam pengembangan kawasan Wisata Bahari Pantai Malalayang. Hal ini berarti bahwa pengembangan Kawasan Wisata Bahari Pantai Malalayang telah mampu mengatasi kelemahannya dengan memanfaatkan kekuatan yang dimiliki, karena berada pada posisi diatas $(3,00)$. Faktor yang merupakan kekuatan dalam strategi pengembangan Wisata Bahari Pantai Malalayang adalah adanya wisata kuliner menjadi pelengkap wisata pantai dengan perolehan skor 0,458. Hal ini menunjukan bahwa selain menikmati keindahan dan panorama pantainya juga bisa menikmati wisata kulinernya yang berada di sepanjang Pantai Malalayang. Adapun kelemahan utama yang di miliki wisata Pantai Malalayang adalah kondisi struktur pantai terdapat banyak bebatuan disepanjang pantai dengan perolehan skor 0,109 . Hal ini dapat dilihat banyaknya bebatuan yang terdapat disepanjang Pantai Malalayang.

\section{Analisis Faktor EFAS (External Strategic Analysis Summary).}

Analisis Kondisi eksternal dilakukan terhadap faktor-faktor strategis yang terdiri atas peluang dan ancaman dalam pengembangan Wisata Bahari Pantai Malalayang Kota Manado. Hasil analisis matriks (EFAS) dapat dilihat pada Tabel 2.

Hasil analisis faktor strategi eksternal melalui peluang dan ancaman mendapat skor total 3,436 yang menandakan bahwa Wisata Bahari Pantai Malalayang Kota Manado berada pada posisi eksternal kuat dalam memanfaaatkan peluang dan mampu mengatasi ancaman yang dihadapi, karena berada pada posisi di atas $(3,00)$. Hal ini berarti bahwa pengembangan Wisata Bahari Pantai Malalayang merespon dengan baik terhadap peluang dan mampu mengatasi ancaman, sehingga dapat menimalkan dampak dari ancaman yang mungkin timbul. Peluang utama dalam pengembangan Wisata Bahari Pantai Malalayang Kota Manado terdapat pada faktor dukungan masyarakat lokal yang berpotensi untuk menjadi tenaga 
kerja dan Menjadi tempat istirahat/ persinggahan orang yang habis melakukan perjalanan dengan perolehan skor 0,656 .

Hal ini menunjukan bahwa dukungan masyarakat lokal yang berpotensi untuk menjadi tenaga kerja dan menjadi tempat istirahat/persinggahan orang yang habis melakukan perjalanan merupakan peluang utama bagi wisata bahari Pantai Malalayang dalam mengatasi ancaman yang ada. Adapun ancaman utama yang ada pada pengembangan wisata bahari Pantai Malalayang Kota Manado adalah bermunculannya berbagai alternatif objek wisata lain di sekitarnya dengan perolehan skor 0,200. Hal tersebut mungkin terjadi karena adanya persaingan antar objek wisata yang ada di Sulawesi Utara pada umumnya. Namun demikian wisata Pantai Malalayang tetap menjadi pilihan banyak orang sebagai tempat rerkreasi karena selain menyediakan kuliner juga sebagai tempat rerkreasi terdekat yang berada di Kota Manado.

\section{Analisis Internal-Eksternal (IE)}

Berdasarkan hasil analisis strategi faktor internal dan faktor eksternal dapat dimasukkan hasilnya ke dalam matriks internal eksternal sebagai tahap pencocokan strategi pengembangan kawasan wisata bahari Pantai Malalayang. Dari hasil analisis sebelumnya telah didapatkan nilai skor total IFAS adalah 3,817 dan EFAS adalah 3,436. Hasil skor total matrix IFAS tersebut berada pada sumbu $\mathrm{X}$ dan skor total dari matrik EFAS berada pada sumbu Y. Posisi pengembangan kawasan wisata bahari Pantai Malalayang dapat dilihat pada Tabel 3.

Berdasarkan skor pembobotan total pada matriks internal eksternal (IE) pada Tabel 3 di atas menunjukkan bahwa kawasan wisata bahari Pantai Malalayang berada pada sel I atau strategi melalui integrasi horizontal yang dapat digambarkan sebagai "tumbuh dan berkembang". Hal ini merupakan strategi utama untuk mengembangkan kawasan wisata dengan cara membangun dan memperluas potensi wisata yang ada guna meningkatkan daya Tarik wisata yang tinggi.

\section{Analisis SWOT}

Dari perhitungan nilai IFAS dan EFAS diperoleh hasil dengan total IFAS adalah 3,817 dan EFAS 3,436, setelah mengetahui kedua nilai tersebut maka dapat disusun dengan diagram analisis SWOT untuk mengetahui posisi relatif Kawasan Wisata Bahari Pantai Malalayang Kota Manado pada kuadran pertama, kedua, ketiga atau ke empat. Hasil perhitungan diatas dapat ditentukan bahwa posisi relatif kawasan wisata bahari Pantai Malalayang Kota Manado berada pada titik kordinat (2,33 dan 1,67) pada kuadran pertama yang menunjukkan bahwa kawasan wisata bahari Pantai Malalayang memiliki kekuatan dan peluang sehingga dapat memanfaatkan peluang yang ada dengan menggunakan kekuatan yang dimiliki. Strategi pengembangan yang sesuai dengan posisi Wisata Bahari Pantai Malalayang adalah strategi mendukung kebijakan pada pertumbuhan wisata. selengkapnya dapat dilihat pada Gambar 1. Diagram SWOT.

Berdasarkan hasil analisis pada Gambar 1. Strategi pengembangan wisata bahari Pantai Malalayang terletak pada posisi kuadran I atau terletak antara peluang eksternal dan kekuatan internal (Mendukung strategi). Selanjutnya menggunakan matriks untuk memperlihatkan strategi-strategi yang dapat dilakukan untuk pengembangan wisata bahari Pantai Malalayang. Strategi- strategi tersebut dimasukkan dalam Matriks Analisi SWOT. Matriks SWOT adalah matriks yang menginteraksikan faktor strategi internal dan eksternal. Matriks ini dapat menggambarkan secara jelas bagaimana peluang dan ancaman yang dihadapi dapat disesuaikan dengan kekuatan dan kelemahan yang dimiliki. Matriks SWOT selanjutnya dapat disajikan pada Tabel 4. 
Tabel 1. Matriks IFAS

\begin{tabular}{|c|c|c|c|c|}
\hline \multirow{3}{*}{ NO } & \\
\hline & FAKTOR- FAKTOR UTAMA INTERNAL & $\begin{array}{l}\mathrm{BOBOT} \\
(a)\end{array}$ & $\begin{array}{l}\text { RANTING } \\
(b)\end{array}$ & $\begin{array}{r}\text { SKOR } \\
(c=a x b)\end{array}$ \\
\hline & \multicolumn{4}{|l|}{ KEKUATAN } \\
\hline 1 & $\begin{array}{l}\text { Memiliki sumberdaya keanekaragaman hayati dan biota laut yang memadai (Terumbu karang, Taman } \\
\text { bawah laut, Panorama pantai, Kualitas air laut) }\end{array}$ & 0,095 & 4,40 & 0,419 \\
\hline 2 & Lokasi yang sangat strategis / mudah di akses. & 0,097 & 4,60 & 0,448 \\
\hline 3 & Prasarana jalan yang memadai & 0,091 & 4,30 & 0,391 \\
\hline 4 & Keberadaannya sudah dikenal banyak pengunjung & 0,093 & 4,35 & 0,405 \\
\hline 5 & Belum adanya biaya masuk ke tempat wisata & 0,087 & 4,45 & 0,386 \\
\hline 6 & Adanya wisata kuliner menjadi pelengkap wisata pantai. & 0,098 & 4,65 & 0,458 \\
\hline 7 & Berdasarkan dari posisinya aman dari arus & 0,072 & 3,50 & 0,252 \\
\hline 8 & Tersedianya peralatan wisata bawah laut (Diving, Snorkling dll) & 0,085 & 3,70 & 0,313 \\
\hline \multicolumn{4}{|c|}{ Sub Total } & 3,072 \\
\hline \multicolumn{5}{|c|}{ KELEMAHAN } \\
\hline 1 & $\begin{array}{l}\text { Masih kurangnya fasilitas sarana dan prasarana obyek wisata (Penyediaan tempat pembuangan sampah, } \\
\text { Penyediaan air bersih / WC umum, Penyediaan Fasilitas Kesehatan,, Penyediaan tempat parkir). }\end{array}$ & 0,056 & 2,30 & 0,129 \\
\hline 2 & Kondisi fisik kios sabua Bulu sudah tidak layak perlu penataan kembali & 0,057 & 2,40 & 0,137 \\
\hline 3 & Lokasinya dekat dari jalan protokol sehingga mengancam keselamatan pengunjung. & 0,057 & 2,25 & 0,129 \\
\hline 4 & Kondisi struktur pantai terdapat banyak bebatuan disepanjang pantai & 0,051 & 2,15 & 0,109 \\
\hline 5 & Belum adanya pengelolaan dari pemerintah setempat/ dikelola oleh masing-masing masyarakat. & 0,060 & 4,00 & 0,241 \\
\hline
\end{tabular}

Tabel 2. Matriks EFAS

\begin{tabular}{|c|c|c|c|c|}
\hline NO & FAKTOR- FAKTOR UTAMA EKSTERNAL & $\begin{array}{l}\text { BOBOT } \\
\text { (a) }\end{array}$ & $\begin{array}{l}\text { RANTING } \\
\text { (b) }\end{array}$ & $\begin{array}{l}\text { SKOR } \\
(\mathrm{c}=\mathrm{axb})\end{array}$ \\
\hline \multicolumn{5}{|c|}{ PELUANG } \\
\hline 1 & Dukungan masyarakat lokal yang berpotensi untuk menjadi tenaga kerja & 0,160 & 4,10 & 0,656 \\
\hline 2 & Sebagai tempat untuk pengenalan dan pemasaran produk kerajinan dan kuliner. & 0,158 & 3,90 & 0,616 \\
\hline 3 & Meningkatnya jumlah wisatawan yang berkunjung di Sulawesi Utara. & 0,152 & 4,10 & 0,623 \\
\hline 4 & Menjadi tempat istirahat / persinggahan orang yang habis melakukan perjalanan & 0,158 & 4,15 & 0,656 \\
\hline \multicolumn{2}{|r|}{ Sub total } & & & 2,551 \\
\hline \multicolumn{5}{|c|}{ ANCAMAN } \\
\hline 1 & $\begin{array}{l}\text { Menurunnya daya dukung lingkungan akibat kurangnya pemahaman wisatawan akan } \\
\text { kelestarian lingkungan }\end{array}$ & 0,092 & 2,45 & 0,225 \\
\hline 2 & $\begin{array}{l}\text { Adanya persaingan dengan daerah lain yang sedang mengoptimalkan pengembangan } \\
\text { pariwisatanya }\end{array}$ & 0,099 & 2,50 & 0,248 \\
\hline 3 & Adanya ancaman bencana alam seperti terjadi angin kecang dan kerasnya ombak. & 0,094 & 2,25 & 0,212 \\
\hline 4 & Bermunculannya berbagai alternatif objek wisata lain di sekitarnya. & 0,089 & 2,25 & 0,200 \\
\hline \multicolumn{2}{|r|}{ Sub total } & & & 0,885 \\
\hline \multicolumn{2}{|c|}{ Total } & & & 3,436 \\
\hline
\end{tabular}

Tabel 3. Matriks IE Kawasan Wisata Bahari Pantai Malalayang

SKOR BOBOT IFAS

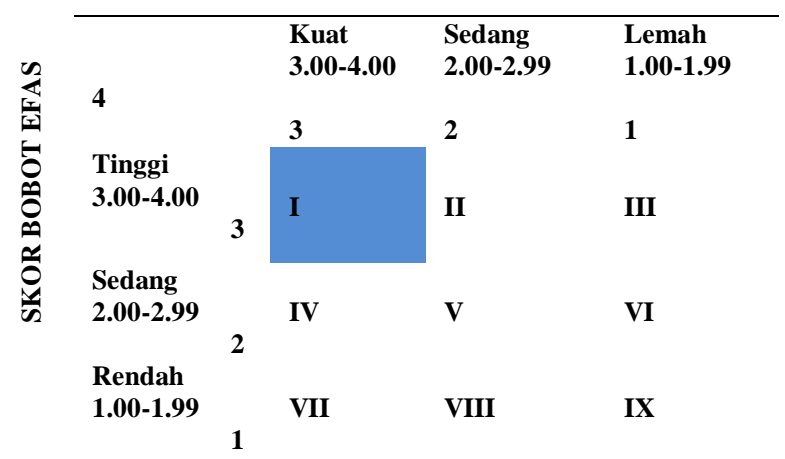

Sumber: Hasil Analisis Data IE 2017

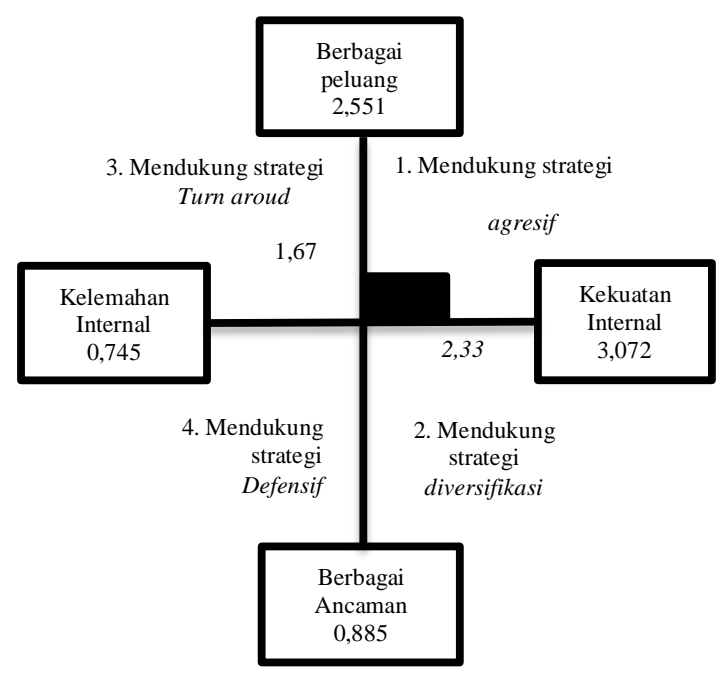

Gambar 1. Diagram Analisis SWOT 


\begin{tabular}{|c|c|c|}
\hline Identifikasi Faktor & Kekuatan (Strength) & $\begin{array}{c}\text { Kelemahan } \\
\text { (Weakness) }\end{array}$ \\
\hline Eksternal & $\begin{array}{l}\text { 1. Memiliki sumberdaya } \\
\text { keanekaragaman hayati dan } \\
\text { biota laut yang memadai. } \\
\text { (Terumbua karang, Taman } \\
\text { bawah laut, Panorama } \\
\text { Pantai, Kualitas air laut) } \\
\text { 2. Lokasi yang sangat } \\
\text { strategis/mudah di akses } \\
\text { 3. Prasarana jalan yang } \\
\text { memadai } \\
\text { 4. Keberadaannya sudah } \\
\text { dikenal banyak pengunjung } \\
\text { 5. Belum adanya biaya masuk } \\
\text { ke tempat wisata } \\
\text { 6. Adanya wisata kuliner } \\
\text { menjadi pelengkap wisata } \\
\text { pantai. } \\
\text { 7. Berdasarkan dari posisinya } \\
\text { aman dari arus } \\
\text { 8. Tersedianya peralatan } \\
\text { wisata bawah laut ( Diving, } \\
\text { Snorkling dll) }\end{array}$ & $\begin{array}{ll}\text { 1. } & \text { Masih } \\
\text { kurangnya } \\
\text { fasilitas sarana } \\
\text { dan prasarana } \\
\text { obyek wisata } \\
\text { (Penyediaan } \\
\text { tempat } \\
\text { pembuangan } \\
\text { sampah, } \\
\text { Penyediaan WC } \\
\text { umum, } \\
\text { Penyediaan } \\
\text { Fasilitas } \\
\text { Kesehatan, } \\
\text { Penyediaan } \\
\text { tempat parkir). } \\
\text { Kondisi fisik } \\
\text { kios sabua Bulu } \\
\text { sudah tidak } \\
\text { layak perlu } \\
\text { penataan } \\
\text { kembali. } \\
\text { Lokasinya dekat } \\
\text { dari jalan } \\
\text { protokol } \\
\text { sehingga } \\
\text { mengancam } \\
\text { keselamatan } \\
\text { pengunjung. } \\
\text { Kondisi struktur } \\
\text { pantai terdapat } \\
\text { banyak bebatuan } \\
\text { disepanjang } \\
\text { pantai } \\
\text { Belum adanya } \\
\text { pengelolaan dari } \\
\text { pemerintah } \\
\text { setempat/dikelol } \\
\text { a oleh masing- } \\
\text { masing } \\
\text { masyarakat. }\end{array}$ \\
\hline $\begin{array}{c}\text { Peluang } \\
\text { (Opportunities) }\end{array}$ & Strategi SO & Strategi WO \\
\hline $\begin{array}{ll}1 . & \begin{array}{l}\text { Dukungan } \\
\text { masyarakat lokal } \\
\text { yang berpotensi } \\
\text { untuk menjadi } \\
\text { tenaga kerja }\end{array} \\
\text { 2. } & \begin{array}{l}\text { Sebagai tempat } \\
\text { untuk pengenalan } \\
\text { dan pemasaran } \\
\text { produk kerajinan } \\
\text { dan kuliner. }\end{array} \\
\text { 3. } & \text { Meningkatnya } \\
\text { jumlah wisatawan } \\
\text { yang berkunjung } \\
\text { di Sulawesi Utara } \\
\text { Menjadi tempat } \\
\text { istirahat / } \\
\text { persinggahan orang } \\
\text { yang habis } \\
\text { melakukan } \\
\text { perjalanan. }\end{array}$ & $\begin{array}{l}\text { Banyaknya wisatawan yang } \\
\text { berkunjung ke pantai } \\
\text { malalayang karena Adanya } \\
\text { wisata kuliner menjadi } \\
\text { pelengkap wisata pantai, } \\
\text { prasarana jalan yang memadai, } \\
\text { dan lokasi yang strategis } \\
\text { sehingga membuka kesempatan } \\
\text { berusaha bagi masyarakat lokal } \\
\text { (S2, S3, S6,O1,O2) } \\
\text { Menjaga dan melestarikan } \\
\text { keanekaragaman hayati dan } \\
\text { biota laut yang dimiliki Pantai } \\
\text { malalayang bersama } \\
\text { masyarakat dan tersedianya } \\
\text { peralatan diving/snorkling } \\
\text { sehingga banyak wisatawan yg } \\
\text { minat datang berkunjung } \\
\text { (S1,S8,O3) }\end{array}$ & $\begin{array}{l}\text { Meningkatnya jumlah } \\
\text { wisatawan yang } \\
\text { berkunjung sehingga } \\
\text { fasilitas sarana dan } \\
\text { prasarana obyek } \\
\text { wisata perlu } \\
\text { dikembangkan } \\
\text { bersama masyarakat, } \\
\text { pihak pemerintah, dan } \\
\text { swasta (W1,W5,O3) } \\
\text { Mendapat Dukungan } \\
\text { dari Masyarakat Lokal } \\
\text { sebagai tempat untuk } \\
\text { pengenalan kuliner } \\
\text { dan banyaknya } \\
\text { wisatawan yang } \\
\text { berkunjung sehingga } \\
\text { kondisi fisik sabua } \\
\text { bulu yang sudah tidak } \\
\text { layak perlu penataan } \\
\text { ulang. (O1,O2,O3,O4, } \\
\text { W2) }\end{array}$ \\
\hline Ancaman (Threats) & $\begin{array}{l}\text { Strategi ST } \\
\end{array}$ & Strategi WT \\
\hline $\begin{array}{ll}\text { 1. } & \begin{array}{l}\text { Menurunnya daya } \\
\text { dukung lingkungan } \\
\text { akibat kurangnya }\end{array} \\
\text { pemahamann } \\
\text { wisatawan akan } \\
\text { kelestarian } \\
\text { lingkungan } \\
\text { 2. } \begin{array}{l}\text { Adanya persaingan } \\
\text { dengan daerah lain }\end{array} \\
\text { yang sedang } \\
\text { mengoptimalkan } \\
\text { pengembangan } \\
\text { pariwisatanya } \\
\text { 3danya ancaman } \\
\text { bencana alam } \\
\text { seperti terjadi } \\
\text { angin kecang dan } \\
\text { kerasnya ombak. } \\
\text { Bermunculannya } \\
\text { berbagai alternatif } \\
\text { objek wisata lain di } \\
\text { sekitarnya. }\end{array}$ & $\begin{array}{l}\text { Kesadaran semua pihak dalam } \\
\text { memelihara keragaman } \\
\text { terhadap sumberdaya alam dan } \\
\text { menjaga kelestarian lingkungan } \\
\text { untuk menghadapai persaingan } \\
\text { dengan daerah lain yang sedang } \\
\text { mengoptimalkan pengembangan } \\
\text { pariwisatanya (S1, T2) } \\
\text { Meskipun adanya persaingan } \\
\text { dengan daerah lain yang sedang } \\
\text { mengoptimalkan pengembangan } \\
\text { pariwisatanya dan adanya } \\
\text { berbagai alternatif objek wisata } \\
\text { lain di sekitarnya, wisata Pantai } \\
\text { Malalayang tetap menjadi } \\
\text { pilihan banyak orang sebagai } \\
\text { tempat rekreasi karena Lokasi } \\
\text { yang sangat strategis/mudah di } \\
\text { akses, Prasarana jalan yang } \\
\text { memadai, Belum adanya biaya } \\
\text { masuk ke tempat wisata, dan } \\
\text { Adanya wisata kuliner menjadi } \\
\text { pelengkap wisata pantai. } \\
\text { (T2,T4,S2,S3,S4,S5,S6) }\end{array}$ & $\begin{array}{l}\text { Perlu adanya } \\
\text { pengawasan dari } \\
\text { pihak keamanan } \\
\text { terhadap pengunjung } \\
\text { agar berhati-hati } \\
\text { untuk menghindari } \\
\text { kecelakaan di tempat } \\
\text { wisata. (W3,W4,T3) } \\
\text { Menurunnya daya } \\
\text { dukung lingkungan } \\
\text { akibat kurangnya } \\
\text { pemahaman } \\
\text { wisatawan akan } \\
\text { kelestarian } \\
\text { lingkungan serta } \\
\text { belum adanya } \\
\text { pengelolaan dari } \\
\text { pemerintah (T1,W5) }\end{array}$ \\
\hline
\end{tabular}

\section{PEMBAHASAN}

Penelitian ini menunjukkan bahwa strategi untuk pengembangan wisata bahari Pantai Malalayang Kota Manado secara umum dapat dirumuskan:

\section{Strategi SO (Strength-Opportunities).}

Meningkatnya jumlah wisatawan yang berkunjung ke pantai malalayang karena adanya wisata kuliner menjadi pelengkap wisata pantai, prasarana jalan yang memadai, dan lokasi yang strategis sehingga membuka kesempatan berusaha bagi masyarakat lokal. Menjaga dan melestarikan keanekaragaman hayati dan biota laut yang dimiliki Pantai malalayang bersama masyarakat dan tersedianya peralatan diving/snorkling sehingga banyak wisatawan yang minat datang berkunjung. Aktivitas rekreasi yang dilakukan pada Kawasan Pantai Malalayang, selain snorkling dan diving (bawah air) juga kegiatan rekreasi pantai (berenang). Di kawasan pantai malalayang terdapat terumbu karang dan kehidupan biota yang ada di dalamnya.

\section{Strategi ST (Strength-Treath).}

Kesadaran semua pihak dalam memelihara keragaman terhadap sumberdaya alam dan menjaga kelestarian lingkungan sekitar untuk menghadapi persaingan dengan daerah lain yang sedang mengoptimalkan pengembangan pariwisatanya, salah satunyadengan melakukan penghijauan sehingga tempat wisata teduh, rindang, dan menambah suasana sejuk di Pantai Malalayang. Meskipun adanya persaingan dengan daerah lain yang sedang mengoptimalkan pengembangan pariwisatanya dan adanya berbagai alternatif objek wisata lain di sekitarnya, wisata Pantai Malalayang tetap menjadi pilihan banyak orang sebagai tempat rekreasi karena belum adanya biaya masuk ke tempat wisata, adanya wisata kuliner menjadi pelengkap wisata pantai, lokasi yang sangat strategis/mudah di akses, serta prasarana jalan yang memadai. Hal ini tentunya memberikan kemudahan untuk lebih banyak wisatawan yang 
berkunjung di kawasan wisata Pantai Malalayang, serta biaya yang murah.

\section{Strategi WO (Weakness-Opportinities).}

Meningkatnya jumlah wisatawan yang berkunjung di Sulawesi Utara sehingga fasilitas sarana dan prasarana obyek wisata perlu dikembangkan bersama masyarakat, pihak pemerintah, dan swasta. Pengembangan fasilitas sarana dan prasarana obyek wisata, melakukan penataan kembali sabua bulu sebagai tempat kuliner yang sudah menyalahi aturan dimana awalnya tempat tersebut disewakan sekarang diperjual belikan. Penataan sabua bulu dengan penyeragaman bangunan dan memberikan nomor kios sehingga wisatawan yang datang berkunjung kembali dapat mengenali sabua bulu favoritnya. Pihak swasta memberikan bantuan berupa karang buatan dari beton (bantuan dari Bank BRI dan perusahaan philips), spot diving parkiran motor dikedalamn 15 meter, pagar iklan, tempat sampah, dan pelataran.

\section{Strategi WT (Weakness-Treath).}

Perlu adanya pengawasan dari pihak keamanan seperti patroli darat dan laut terhadap pengunjung untuk menghindari kecelakaan di tempat wisata. Menurunnya daya dukung lingkungan akibat kurangnya pemahaman wisatawan akan kelestarian lingkungan serta belum adanya pengelolaan dari pemerintah. Beberapa masalah mendasar yang dihadapi Kota Manado dalam pengembangan pariwisata bahari adalah kerusakan sumberdaya yang justru menjadi obyek wisata bahari. Ancaman aktual dapat datang dari intervensi manusia melalui pembuangan sampah ke laut. Sampah ini mengotori kawasan pantai yang membuat air keruh sehingga membatasi jarak pandang para diving hanya 7 meter.

Hal ini juga diakibatkan karena letak pantai dekat dengan daerah pemukiman. Efek lain dari sampah menimbulkan eutrofikasi sehingga mempengaruhi sumberdaya alam sehingga terjadi ketidakseimbangan sistem lingkungan misalnya merebaknya populasi hewan pemakan karang yang turut mempengaruhi degradasi terumbu karang.

\section{KESIMPULAN DAN SARAN}

\section{Kesimpulan}

Dari hasil dan pembahasan yang telah dikemukakan maka dapat di simpulkan bahwa strategi pengembangan Wisata Bahari Pantai Malalayang berdasarkan hasil analisis SWOT yang telah dilakukan, terletak pada posisi kuadran I atau strategi melalui integrasi horizontal, yang terletak antara peluang eksternal dan kekuatan internal. Hal ini merupakan strategi utama untuk mengembangkan kawasan wisata dengan cara membangun dan memperluas potensi wisata yang ada guna meningkatkan daya Tarik wisata yang tinggi, dengan cara menjaga sumberdaya keanekaragaman hayati dan biota laut yang dimiliki Pantai Malalayang, mengembangkan fasilitas sarana dan prasarana obyek wisata, dan mengembangkan wisata kuliner yang menjadi pelengkap wisata pantai.

\section{Saran}

Adapun saran dari penelitian ini adalah: Melestarikan dan manjaga keanekaragaman hayati dan biota laut yang dimiliki Pantai malalayang dan lingkungan sekitar serta meningkatkan fasilitas sarana dan prasarana untuk mendukung obyek wisata Pantai Malalayang, Sabua bulu perlu penataan ulang, bukannya dilakukan penggusuran, Perlu adanya pengelolaan dari pihak pemerintah dan swasta serta masyarakat agar lebih terarah dan berjalan dengan baik serta kedua belapihak sepat untuk bekerjasama dalam mengembangkan obyek Pariwisata Pantai Malalayang secara berkelanjutan.

\section{DAFTAR PUSTAKA}

Akhmad Zaenal. 2015. Strategi Pengembangan

Kawasan Wisata Takabonerate di Kabupaten Selayar. Jurnal Pepatuzdu. Selayar.

Anonim. 2009. Undang-undang No. 10 Tentang Kepariwisataan.

Asia. 2004. Strategi Pengembangan Pulau Lanjukang Untuk Destinasi Wisata Bahari Di Makassar. Tesis tidak diterbitkan. Program Pascasarjana PPW-UNHAS Makassar. 
Bappeda,2016.Rencana Pembangunan Jangka Menengah Daerah 2016-2021.Kota Manado.

BPS Sulut. 2014. Sulawesi Utara dalam Angka, Manado Sulut.

Dinas Pariwisata Kota Manado.2012.Rencana Induk Pengembangan Pariwisata Daerah. Kota Manado.

Dinas Pariwisata Kota Manado. 2015. Data Kunjungan Wisatawan ke Sulawesi Utara. Manado Sulut.

Fandeli, C, Et A1. 2000. Pengusahaan Ekowisata. Fakultas Kehutanan Universitas Gadjah Mada. Yogyakarta

Ferdinandus Alfriani Maria 2014. Studi Pengembangan Wisata Bahari Untuk Meningkatakan Kunjungan Wisatawan Di Pantai Natsepa Kota Ambon. Jurnal. Jurusan Destinasi Pariwisata, Fakultas Pariwisata Kota Ambon.

Google Map 2015. Gambar Peta Photo Pantai Malalayang Kota Manado

Hadinoto, K. 1996. Perencanaan dan Pengembangan Destinasi Pariwisata. Universitas Indonesia. Press: Jakarta.

Hidayat Marcelia. 2012. Strategi Perencanaan dan Pengembangan Objek Wisata (Studi Kasus: Pantai Pengandaran Kabupaten Ciamis Jawa Barat). Jurnal. Politeknik Negeri Bandung.

Irham, 2014. Strategi Pengembangan Kawasan Wisata Pulau Karampuang Kabupaten Mamuju. Program Pascasarjana PPWUNHAS. Makassar.

Kinnear and Taylor. 1991. Marketing Research anApplied Approach McGraw Hill International Edition.

Unga, Kartini La Ode. 2011. Strategi Pengembangan Kawasan Wisata Kepulauan Banda. Tesis tidak diterbitkan.Program Pascasarjana PPWUNHAS. Makassar.

Rangkuti. 2005. Analisis SWOT Teknik Membedah Kasus Bisnis Reorientasi Konsep Perencanaan Strategis Untuk Menghadapi Abad 21. PT. Gramedia Pustaka Utama. Jakarta

Rangkuti, F. 2013. Teknik Membedah Kasus Bisnis Analisis SWOT cara Perhitungan bobot, rating, dan OCAL. Gramedia Pustaka Utama. Jakarta.
Ruslan. 2013. Strategi Pengembangan Wisata Bahari Kabupaten Takalar. Program Pascasarjana PPW-UNHAS. Makassar.

Spillane, James J. 1994. Ekonomi Pariwisata, Sejarah Dan Prospeknya. Kanisius. Yogyakarta

Supriadi, M. 2005. Strategi Pengembangan Objek Wisata Malino Berbasis Karakteristik Wisatawan. Tesis tidak diterbitkan. Program Pascasarjana PPW-UNHAS. Makassar.

Sugiyono. (1999). Statistika Untuk Penelitian. Bandung: CV. Alfabeta Umar H. 1999. Riset SDM dalam Organisas. PT. Gramedia Pustaka Utama. Yogyakarta.

Warpani dan Indira. 2007. Pariwisata dalam tata ruang wilayah. ITB. Bandung.

Wijayanto Dian. 2012. Strategi Pengembangan Pariwisata Mangrove di Kawasan Konservasi Perairan Nusa Penida. Jurnal. Saintek Perikanan. Universitas Diponegoro, Semarang. 